\title{
La construcción de la nación colombiana a la luz del modelo porfirista
}

\section{The Construction of the Colombian Nation in Light of the Porfirian Model}

\author{
Adriana María Suárez Mayorga \\ Universidad de La Salle. Bogotá, D.C., Colombia \\ ORCID: 0000-0002-6910-8859 \\ amsuarez@unisalle.edu.co
}

Resumen: El artículo analiza el interés que suscitó el gobierno de Porfirio Díaz entre los letrados colombianos de finales del siglo xIx y comienzos del $\mathrm{xx}$ como modelo a seguir para construir la nación. Inscrita en este marco, la disquisición aborda la manera en que los connacionales recurrieron al ejemplo mexicano -fuera para avalarlo o criticarlo- en aras de plantear soluciones a la crisis en la que entonces se encontraba el país. Metodológicamente, la investigación se fundamenta en fuentes primarias de la época (en particular, los libros y periódicos de esos años), que son confrontadas con la bibliografía que se considera cardinal para aproximarse al tema. Fundada en la certeza de que es necesario empezar a problematizar la historia nacional cambiando la escala de análisis, la conclusión principal sostiene que, allende las similitudes, dicho modelo no fructificó en el medio colombiano porque implicaba transgredir tres principios inquebrantables: republicanismo, democracia e institucionalidad.

Palabras clave: Colombia; Regeneración; Rafael Reyes; Porfirio Díaz; siglos XIX y XX.

Abstract: The article analyzes the interest generated by the government of Porfirio Díaz among Colombian intelligentsia of the late 19th and early 20th centuries as a model for nation building. Within this context, it examines the way Colombians used the Mexican example - either to endorse or criticize it- 
in order to propose solutions to the crisis in which the country was immersed. Methodologically, the research is based on the primary sources of the time (particularly books and newspapers), which are compared with the main literature on the subject. On the basis of the principle that is essential to begin to problematize national history by changing the scale of analysis, the main conclusion is that, beyond the similarities, this model failed to flourish in the Colombian setting because it involved violating three unshakable principles: republicanism, democracy and institutionality.

Key words: Colombia; regeneration; Rafael Reyes; Porfirio Díaz; 19th and 20th centuries

Fecha de recepción: 8 de enero de 2016 Fecha de aceptación: 11 de octubre de 2016

L os últimos decenios del siglo xix colombiano fueron notablemente prolíficos en la producción de escritos en donde se reflexionaba acerca de cómo forjar la Nación; algunos letrados de la época, preocupados por dilucidar por qué el territorio patrio se encontraba "a la retaguardia de los demás países hermanos", se dedicaron a examinar las causas del atraso con miras a formular soluciones orientadas a lograr que Colombia "se colocara en el puesto que debía ocupar", en virtud de su "historia" e "ilustración" (Aguilar, 1884 , pp. $5-6)^{1}$

Las disquisiciones efectuadas al respecto centraban la discusión en torno al modelo de gobierno que se debía adoptar. La idea que empezó a calar entre los connacionales sugería que era preciso acabar con el federalismo para instituir en su reemplazo un Estado fuerte que eliminara para siempre de nuestra idiosincrasia "la maldita política" que había "depravado, arruinado y desacreditado a la Patria" (Aguilar, 1884, pp. 8-9).

Tras el triunfo de la Regeneración, la posibilidad de que este último precepto se hiciera realidad, aumentó. La promulgación de una carta magna que certificaba la existencia de un país unificado alrededor del poder central fue interpretada inicialmente como un paso inequívoco en esa dirección; sin

${ }^{1}$ La expresión en cursiva se encuentra en el prólogo del libro de Frédéric Martínez (2001), escrito por Marco Palacios. La palabra letrados remite a los planteos de Ángel Rama (1984). La obra de Aguilar hacía referencia a México, Centro-América, Venezuela, Ecuador, Perú, Bolivia, Chile y Argentina (Aguilar, 1884, p. 293).

\section{()(1) $\$$}


embargo, a medida que los regeneradores se afianzaron en el poder, fue ostensible que el establecimiento de un régimen centralista no necesariamente implicaba un cambio en las costumbres más arraigadas: el partido de gobierno, el nacionalismo, en vez de extirpar las prácticas clientelistas, hizo uso de ellas para favorecer a los círculos que comulgaban con el oficialismo e imponer severas medidas de represión a la oposición. ${ }^{2}$

Fruto de lo anterior fue el desencadenamiento de pequeñas conflagraciones que, al no conseguir dar respuesta a los problemas latentes, crearon el ambiente propicio para el estallido de la guerra de los Mil Días (1899-1902). La crueldad de la confrontación originó que la prensa bogotana asegurara que, aparte del establecimiento de un gobierno firme capaz de pacificar el territorio, era imperioso concretar el deslinde de la administración de la política, es decir, instituir una "administración honrada" que estuviera encauzada a acometer los adelantos materiales que le urgían a la patria. ${ }^{3}$

La asunción de este postulado suponía seguir a carta cabal el ejemplo mexicano, de antaño ya estudiado como paradigma de lo que era una nación: si desde principios de la década del ochenta las acciones de Porfirio Díaz habían deslumbrado a los connacionales por la seguridad, la estabilidad y la tranquilidad que su mandato le había dado al pueblo de México, ahora, en pleno cambio de siglo, se creía que la aplicación de su lema "mucha admi-

${ }^{2}$ Marco Palacios (2002) asegura que "el centralismo de la Regeneración se quedó en el papel porque la fórmula de la República unitaria contrapuesta al localismo de la República federal, estuvo lejos de consumarse" (p. 271). Esta afirmación se pone en entredicho al estudiar la esfera local; si bien es cierto que las elites regionales mantuvieron su dominio, también lo es que las tensiones políticas del periodo se explican precisamente en virtud de la pugna poder central-poder seccional-poder municipal que se fraguó a causa del reclamo que los departamentos y los municipios hicieron al gobierno porque, según se decía en la época, los estaba asfixiando. Testimonio de ello es la cita siguiente: "los pueblos excesivamente centralizados son pueblos enfermos, porque la vida entera nacional se les agolpa á la cabeza como una congestión, y son los más expuestos á esas apoplejías fulminantes que se llaman revoluciones y golpes de Estado" (Uribe Uribe, 1910, p. 237). Importa recalcar que estas palabras, pronunciadas el 3 de septiembre de 1910 por el máximo líder del liberalismo, quien además hizo parte de la Asamblea Nacional creada por Rafael Reyes en 1905, revelan que el general tampoco logró materializar la descentralización administrativa prometida en la Constitución de 1886 (véase Suárez Mayorga, 2015). Inclusive, el propio Marco Palacios (2001, pp. 69-70) reconoce la situación al comentar las razones por las cuales se produjo la separación de Panamá.

3 "Honradez administrativa", La Opinión, 17 de septiembre de 1900, p. 93. El editorial citado no tiene autor, por lo que se referencia con el nombre del periódico en el que se publicó. La carencia de firmas en los artículos fue frecuente en estos años, así que en adelante se mantendrá el mismo sistema de referencia.

\section{()(1) $\$$}


nistración y poca política" podría sacar a la República de la crisis en que se hallaba (Roeder, 2013, p. 384). ${ }^{4}$

La materialización de este ideal en un programa de gobierno concreto se dio con la llegada a la presidencia del general Rafael Reyes, un confeso admirador del porfiriato, pero sobre todo, del hombre que lo había creado: su fascinación por el dignatario mexicano estaba ligada a las similitudes que ambos presentaban en el carácter, pues los dos confiaban plenamente en la preeminencia de la "virtud maquiaveliana" sobre la fortuna o el azar (Colomer, 1997, p. 82). ${ }^{5}$ La convicción que compartían al respecto presuponía que ese virtuosismo, al mismo tiempo que los dotaba de las calidades morales para sobresalir, les confería la capacidad de voltear a su favor cualquier situación adversa. ${ }^{6}$

\section{LOS CIMIENTOS DEL PROBLEMA}

Teniendo en cuenta la introducción previa, el objetivo del presente artículo es analizar el interés que suscitó entre los letrados de la época el gobierno de Porfirio Díaz como modelo a seguir para construir la nación colombiana a finales del siglo xIx y comienzos del xx. Inscrita en este marco, la disquisición girará en torno a la manera en que los connacionales recurrieron al ejemplo

${ }^{4}$ Hacia 1887, según lo afirma Alfredo Gómez Muller (2011), Rafael Núñez elogió al gobierno de Porfirio Díaz porque el mexicano "había tenido que hacer caso omiso de la república" para que México se encontrara en el "camino de la civilización" (p. 147).

${ }_{5}$ En el capítulo vi de El príncipe, se afirma que el gobernante "menos auxiliado por la fortuna” era el que más perduraba en el poder (Maquiavelo, 1983, p. 24). Los letrados colombianos ciertamente utilizaron la obra del florentino para reflexionar sobre el país; de hecho, en 1900 un editorialista escribió: "como si el maquiavelismo, que todo lo sacrifica al éxito, fuera el Código de los gobernantes cristianos, el Sr. Palacio [ministro de Gobierno de Manuel Antonio Sanclemente], tomóle como norma de su conducta". espectador, "Es inútil", La Opinión, 4 de septiembre de 1900, p. 54.

${ }^{6}$ Ralph Roeder (2013) sostiene que Porfirio Díaz hizo de la política uno de los ejes de su régimen, pero la enfocó a "dirigir los destinos de la nación" a través de "subordinar las ambiciones ajenas a la suya propia, sembrando cizaña entre las aspiraciones rivales y manejando los móviles invariables de la naturaleza humana a su antojo" (p. 384). En la historiografía mexicana actual se ha reivindicado su carácter de político nato que sabía descifrar muy bien a la gente para usarlo en su propio beneficio. Rafael Reyes, por su parte, era un hombre bastante supersticioso e incluso, como lo narra en sus Memorias, texto que escribió entre 1911 y 1915, creía que estaba predestinado por la Divina Providencia para realizar grandes proyectos.

\section{()(1) $\$$}


mexicano -fuera para avalarlo o criticarlo- con el fin de plantear soluciones a la crisis en la que entonces se encontraba el país. ${ }^{7}$

Otorgarle prioridad a esta cuestión supone centrar la atención en la realidad histórica del periodo, la cual es examinada a través de una exhaustiva recopilación de fuentes primarias. ${ }^{8}$ Metodológicamente, por consiguiente, la argumentación no se sustentará en la bibliografía secundaria que existe en relación con las décadas en estudio, sino que se fundamentará en los libros y los periódicos de esos años con el propósito de entender, a partir de la voz de los propios actores, lo que ocurrió. ${ }^{9}$

La periodización escogida corresponde a la etapa conocida como la Regeneración, la cual comprende -y este es uno de los postulados cardinales del escrito- los años que van de 1886 a $1910 .{ }^{10}$ La premisa que aquí se sostiene es que ambas fechas encarnan tanto el comienzo como el fin de la lógica política que caracterizó a los regeneradores: a saber, aquella basada en un centralismo a ultranza, que en el caso de Rafael Reyes se exacerbó al punto de adquirir la forma de un centralismo dictatorial (Suárez Mayorga, 2015, p. 221). ${ }^{11}$

La ideología regeneracionista, como se demostró en una pesquisa precedente, se cimentó en el concepto de perfección moral acuñado por Rafael Núñez con miras a legitimar la labor de reconstrucción que, a su juicio, preci-

7 Tal acotación faculta para: a) indicar el carácter inédito de este trabajo, pues hasta ahora la historiografía colombiana no ha abordado con rigor el tema propuesto, y b) determinar los límites de la pesquisa: aquí no se hará un estudio comparado entre México y Colombia, ni entre Porfirio Díaz y Rafael Reyes; tampoco se ahondará en la ideología de los líderes de la Regeneración, ni en la influencia que tuvo la religión católica en el movimiento regenerador, ni en las particularidades del pensamiento reyista. Todas estas temáticas darían lugar, por sí mismas, a la elaboración de varios artículos.

${ }^{8}$ Indiscutiblemente, la literatura sobre el porfiriato es mucho más amplia que la que ha surgido en el medio colombiano con respecto a la Regeneración o a la figura de Rafael Reyes; sin embargo, debido a las restricciones editoriales, en este escrito sólo se referenciarán aquellos textos que se consideran cardinales para respaldar la argumentación.

${ }^{9}$ Las páginas que siguen se fundamentan en la convicción de que es preciso reconsiderar planteamientos historiográficos que hasta ahora se han mantenido vigentes en el ámbito académico colombiano sin que se haya indagado a profundidad cuáles son las bases concretas en las que se sustentan.

${ }^{10}$ Vale anotar que antes de la promulgación de la Constitución de 1886, el país estaba organizado en un sistema federal compuesto por nueve estados soberanos (Cundinamarca, Antioquia, Magdalena, Panamá, Bolívar, Santander, Boyacá, Tolima y Cauca).

${ }^{11}$ Historiográficamente existen diversas posturas con respecto a la periodización de la Regeneración: por ejemplo, según Luis Javier Ortiz Mesa (2010), se prolongó de 1878 a 1902; según Jorge Orlando Melo (1989), de 1885 a 1896; según Frédéric Martínez (2001), de 1888 a 1900; según Marco Palacios (2002), de 1878 a 1900, y según Eduardo Posada Carbó (2015), de 1880 a 1894.

\section{()(1) $\$$}


saba el país para lograr entrar "con paso seguro en la vía de la verdadera civilización, que era también la del verdadero progreso" (Núñez, 1986, p. 53). ${ }^{12}$ La manera de cristalizar esa moralización de los sentimientos que iba a "regenerar o rehabilitar" a la República, consistió en imponer "el principio de la garantía del orden" (moral, político, social) en el territorio nacional, para de este modo desterrar "la anarquía, el crimen, la ruina" y asentar definitivamente la paz en el territorio (Núñez, 1945a, p. 327; Núñez, 1945b, pp. 135-136). ${ }^{13}$ El proyecto político regenerador, caracterizado por ser centralista, autoritario, segregador, civilizador, "exclusivista, católico", llevado a su máxima expresión durante la dictadura de Rafael Reyes, tiene su origen en esta conceptualización (Gómez Muller, 2011, p. 150).

\section{EL MODELO PORFIRISTA VISTO DESDE LOS LETRADOS COLOMBIANOS}

Las descripciones llevadas a cabo por los cronistas extranjeros que visitaron el país durante la segunda mitad del siglo xix concordaban en advertir que la causa principal de que Colombia progresara "lentamente" era el fervor político que caracterizaba a su población. Los asiduos debates que se suscitaban en torno a quién iba a ser el próximo candidato presidencial mantenían "en

${ }^{12}$ Las transformaciones producidas en la dimensión moral de los hombres, según Rafael Núñez (1945b), originaban el perfeccionamiento de la vida social, económica y política, pues "el progreso de los sentimientos morales era causa y efecto de la civilización". Interesa subrayar, que ese "desarrollo moral incesante" era para el cartagenero "obra inseparable del sentimiento religioso" (pp. 82 y 85 ).

${ }^{13}$ El término en cursiva se encuentra en Núñez (1945b, p. 135). La historiografía tradicional -como lo explica Múnera (2011) - presenta a Rafael Núñez como "el reformador modernizante, promotor de una idea pragmática y positivista del orden y progreso", y a Miguel Antonio Caro como "el tradicionalista hispanizante, defensor de un orden social orgánico estratificado" (p. 15). Aunque en este artículo no se profundizará en el tema, el hecho de que se siga aseverando -en la línea trazada por Raimundo Rivas-que la Constitución de 1886 fue obra del filólogo bogotano, quien se "apartó sustancialmente de los anhelos regeneradores, de los de su jefe y de las causas que habían determinado esa saludable orientación”, es prueba fehaciente del desconocimiento que existe del pensamiento nuñista (p. 52). Al respecto, véase Suárez Mayorga (2015, pp. 72-81). Hace décadas, Malcolm Deas (1983) llamó la atención sobre la necesidad de efectuar "una monografía con algo de sentido comparativo" sobre Miguel Antonio Caro con miras a entender apropiadamente su gobierno. Los historiadores colombianos todavía están en deuda de concretar esta indicación (p. 56).

\section{()(1) $(3$}


constante alarma los ánimos", mostrando con ello que quedaba "todavía un resto de fiereza y de atraso bárbaros" (García Mérou, 1989, p. 119). ${ }^{14}$

Tales observaciones, condensadas en lo que se llamó en la década de 1880 "el afán de la política", encontraron rápidamente eco entre los letrados colombianos de la época (García Mérou, 1989, pp. 119-120). Uno de ellos, el presbítero Federico Cornelio Aguilar, escribió hacia 1884 un libro en donde afirmaba que eran la "holgazanería" y "las continuadas y perpetuas agitaciones políticas" las que mantenían a la sociedad en un desasosiego permanente que "desviaba y pervertía la actividad e inteligencia nacionales", "malgastándolas en luchas fratricidas y sangrientas” (Aguilar, 1884, pp. 5-6, 26 y 217).

La médula de su razonamiento sugería que la responsabilidad de lo ocurrido era de quienes seguían absorbidos por "teorías" en vez de plasmar en obras concretas la marcha por "el camino del progreso". Mientras que argentinos, chilenos, paraguayos, costarricenses, guatemaltecos, salvadoreños y mexicanos habían dejado el mundo de las ideas para concentrarse en el de los hechos, los colombianos continuaban sumergidos en la planeación de "revueltas intestinas" que únicamente servían para sumir al país en la "miseria, la ignominia y el descrédito". El "atraso" de la patria, en consecuencia, se debía a que todavía los connacionales no se percataban de que sin "un comercio activo y cuantioso, un erario bien previsto, muchas leguas de ferrocarriles y fuertes naves de guerra", era imposible alcanzar la prosperidad que exhibían otras naciones del continente (Aguilar, 1884, pp. 191, 194, 258 y 260). A su modo de ver, prueba fehaciente de esto era México, que:

antes agitado con perennes revoluciones, desgarrado por los odios de partido y desacreditado por el vandolerismo [sic] que se [había desencadenado] en su territorio, [había] emprendido nuevo sendero desde 1877, o más bien, desde 1879, año en el cual [habían terminado] completamente las guerras civiles y la brega y vaivén de la política, bajo el poderoso influjo del General Porfirio Díaz (Aguilar, 1884, p. 194). ${ }^{15}$

Interesa recalcar que la referencia al porfiriato efectuada por Federico C. Aguilar no era producto de la casualidad sino que ejemplificaba el régi-

${ }^{14}$ Apreciaciones similares se hallan en Miguel Cané (1992) quien, al igual que Martín García Mérou (1989), estuvo en Colombia al iniciar la década de 1880.

${ }^{15}$ Las palabras que se encuentran entre corchetes no pertenecen al original; se introducen para mantener la coherencia gramatical en la redacción. Este sistema se mantendrá a lo largo de todo el artículo.

\section{()(1) $\$$}


men que el sacerdote jesuita creía que se debía instaurar en el país. El paralelismo que se podía hacer con los mexicanos por el grado de conflictividad al que habían llegado en el pasado, lo facultaba para proponer un modelo de gobierno que combinaba dos rasgos: a) la firmeza, que era imprescindible para sembrar la paz en la nación, y b) la proscripción de los males de la política, que era condición sine qua non para "aplacar la fiebre revolucionaria" en aras de dar vía libre al desarrollo comercial e industrial (Aguilar, 1884, p. 197).

La tipología presentada por el clérigo claramente se afincaba en la esperanza de que surgiera una figura descollante en la arena pública que dirigiera a la patria con autoridad. Fuera el mandatario que fuera, utilizara los medios que utilizara, lo importante era, en síntesis, que acabara con el federalismo reinante con miras a erigir un Estado fuerte, capaz de controlar los clientelismos regionales y sustentado en "tres elementos de regeneración": "paz, unión y trabajo" (Aguilar, 1884, p. 270).

\section{EL PORFIRIATO EN LA REGENERACIÓN}

La aprobación de la Constitución de 1886 atendió, al menos en la letra, tales requisitos: imponiendo de súbito un principio de unidad dentro de un entorno fuertemente disgregado, Colombia se convirtió en una república unitaria constituida alrededor de "la fórmula centralización política y descentralización administrativa”, la cual fue acuñada para dominar políticamente el territorio nacional desde el centro, pero sin quebrantar la legitimidad que otorgaba el respaldo regional. ${ }^{16}$

La realidad demuestra, empero, que ni Rafael Núñez, ni Miguel Antonio Caro, líderes indiscutidos del movimiento regenerador, consiguieron dar cabida a la administración en sus respectivos mandatos, acaecer que sumió al país en una inestabilidad política, económica y social de gran magnitud. ${ }^{17}$

16 "La administración", La Opinión, 26 de septiembre de 1900, pp. 125-126. Las dos instituciones que se crearon para materializar este precepto fueron las asambleas departamentales y los consejos municipales. Los miembros de estas corporaciones debían ser elegidos por sufragio popular directo, es decir, por todos los "varones colombianos mayores de veintiún años" que ejercieran profesión, arte u oficio, o tuvieran ocupación lícita "u otro medio legítimo y conocido de subsistencia" (República de Colombia, 1888, pp. 7-8).

${ }^{17} \mathrm{La}$ fragmentación del conservadurismo en dos bandos (nacionalistas e históricos), sumada al recrudecimiento de la inconformidad del liberalismo, puso de manifiesto hasta dónde la frase de Federico C. Aguilar de que "los versos y la literatura, solos, llevaban a los hombres al hospital y á las naciones á la ruina”, era acertada (Aguilar, 1884, p. 191).

\section{()(1) $\$$}


Las elecciones de 1898 fueron el preámbulo de esta situación: sabiendo que estaba constitucionalmente inhabilitado para continuar en el cargo, el gobernante regente decidió candidatear a dos conservadores "prehistóricos", como lo eran Manuel Antonio Sanclemente y José Manuel Marroquín, para acallar las especulaciones de quienes creían que iba a implementar en suelo patrio "el sistema adoptado en México del continuismo en el poder". ${ }^{18}$

Los conservadores "oposicionistas" que disentían de las tácticas caristas y los liberales que estaban en abierta pugna con el oficialismo, también postularon sus propios candidatos aferrados a la esperanza de que el general Rafael Reyes o Miguel Samper consiguieran el triunfo para una $u$ otra colectividad. ${ }^{19}$ La animosidad reinante en los días previos a los comicios se tradujo en una discusión encarnizada entre los periódicos que apoyaban alguna de las tres candidaturas, siendo el núcleo de la querella la manera en que el régimen había manejado "la cosa pública", es decir, los diferentes ramos que componían la Administración nacional. ${ }^{20}$

Inscrito en este marco, el periódico El Orden publicó un artículo titulado "Los gobiernos de círculo" en donde aseguraba que el gran inconveniente de los regímenes cuyo "personal estaba circunscrito a un corto número de adeptos" residía en que quienes lastimaban los intereses de los ciudadanos eran los mismos que tenían la autoridad para impartir sentencia frente al

${ }^{18}$ El Sufragio, 8 de noviembre de 1897, s. p. Los aportes a la historia electoral colombiana realizados por David Bushnell (1975), Malcolm Deas (1993) y Eduardo Posada Carbó (1995), artículo este último que sirvió como base de sus investigaciones posteriores, son innegables; sin embargo, como se ha recalcado en otras pesquisas, son estudios generales que plantean proposiciones que deben ser revisadas a través de estudios sistemáticos sobre la materia (Suárez Mayorga, 2006). En la investigación realizada para la tesis doctoral de hecho se demostró, a la luz de un examen detallado de las elecciones para concejales municipales bogotanos verificadas durante la Regeneración, que el panorama político local difiere notoriamente del que historiográficamente se ha presentado en relación con los comicios presidenciales (Suárez Mayorga, 2015).

19 "Rumores", El Orden, 27 de febrero de 1897, p. 25. Los "procedimientos represivos" que Miguel Antonio Caro utilizó durante su mandato originaron que la política nacional se estructurara -siguiendo el análisis realizado por Carl Schmitt (1991) - alrededor de la dicotomía amigo-enemigo, acaecer que generó el clima propicio para la aparición de otro enfrentamiento (Martínez Carreño, 1999, p. 27). Es pertinente mencionar que los letrados de la época ya planteaban, en sus propios términos, esta dualidad: en un artículo publicado en 1904 en el periódico El Comercio se afirmaba que los colombianos tenían una "noción confusa de autoridad", pues para "los conservadores netos era algo que podía atreverse a todo", mientras que para los que "andaban en el otro extremo, la autoridad era el enemigo". "En defensa de Bogotá”, El Comercio, 18 de junio de 1904, s. p. (la abreviación s. p. significa sin paginación).

20 "Los gobiernos de círculo", El Orden, 24 de julio de 1897, p. 126.

\section{()ㅜ(1) $\$$}


agravio, ocasionando de este modo que la imparcialidad -base de toda buena administración pública- quedara anulada. ${ }^{21}$

La mención a los irrisorios progresos que el país había hecho en el campo administrativo (que más bien suponían retrocesos) estaba estrechamente ligada a la reprobación que suscitaba la figura del dictador en el medio colombiano: sustentado en que éramos una nación democrática, el diario criticaba con ahínco el accionar de aquellos gobernantes que "perdían de vista que eran mandatarios, es decir, administradores, y llegaban a creer que eran amos" de sus pueblos. ${ }^{22}$

La aserción precedente mostraba otra cara de la propensión que sentían los letrados finiseculares a hacer comparaciones con el modelo mexicano: la idea de un gobierno en el que el mandatario podía ser reelegido indefinidamente con el argumento - como lo afirmaba Francisco Bulnes- de que "el dictador bueno era un animal tan raro, que la nación que poseía uno debía prolongarle no sólo el poder, sino hasta la vida", representaba para buena parte de la opinión pública nacional una abominación (González y González, 2010, p. 17).

Testimonio de lo anterior fue justamente la postura que adoptó Miguel Antonio Caro quien, consciente de que debía mantener la "pantalla" democrática y estando plenamente convencido de que una vez elegidos sus candidatos podría recuperar el mando, puso al servicio de su causa todo el andamiaje institucional. ${ }^{23}$ Los resultados de los escrutinios, a pesar de las denuncias elevadas por los liberales a causa del "atropello sistemático a sus derechos políticos", terminaron confirmando el triunfo nacionalista. ${ }^{24}$

21 "Los gobiernos de círculo", El Orden, 24 de julio de 1897, p. 126.

22 "Los gobiernos de círculo", El Orden, 24 de julio de 1897, p. 126.

23 “Los dos Manueles. Presidente y... ¿Vicepresidente?...", El Orden, 14 de octubre de 1897, p. 169. La preocupación tanto de los conservadores históricos como de los liberales era que se conjugaran tres situaciones: a) que Manuel Antonio Sanclemente saliera elegido presidente pero dejara el cargo por sus problemas de salud; $b$ ) que José Manuel Marroquín renunciara a la vicepresidencia, y c) que Miguel Antonio Caro fuera nombrado designado por el Congreso. La confluencia de estos acontecimientos le dejaría al filólogo bogotano el camino libre para gobernar durante el sexenio 1898-1904 y, una vez en el mando, podría maquinar su reelección para el periodo 1904-1910.

${ }^{24}$ El Sufragio, 25 de octubre de 1897, s. p. Las denuncias sobre las irregularidades cometidas en las votaciones fueron numerosas; en Bogotá los jurados de votación no sólo habían procedido "irregularmente al admitir listas de individuos llevadas por sus parciales políticos sin estar presentes los reclamantes", sino que además habían incluido en los registros a "empleados de los distintos ramos administrativos, políticos y militares, sin comprobación de su calidad legal". "Crónica electoral", El Sufragio, 4 de diciembre de 1897, s. p.

\section{(이요}


La noticia fue recibida por los periódicos afines al régimen como un vaticinio de que se emprendería "una era de calma" tras "la prolongada lucha que tantos males había ocasionado a la Patria”. ${ }^{25}$ La validación de que el país se hallaba finalmente en el camino correcto provino de México, accionar que resulta lógico a la luz de la correlación que de antaño se había perfilado. El trisemanario Bogotá publicó un artículo escrito por Victoriano Agüeros, director del periódico católico El Tiempo, en el que, a la par que exaltaba los valores democráticos del régimen carista, criticaba las prácticas antidemocráticas porfiristas:

Ha terminado, al fin, el debate electoral en Colombia, que por varios meses conmovió hondamente á aquella República [...]. El triunfo de la dupla Sanclemente-Marroquín significa el de la obra regeneradora y cristiana de D. Rafael Núñez [...]. Por la atención continuada que venimos prestando de tiempo atrás á aquellos sucesos y la lectura perseverante de varios órganos de la prensa colombiana que recibimos, creemos haber estado en condiciones para formarnos [...] una idea bastante justa de la [administración de Colombia]. En nuestro concepto, el gobierno del señor Caro, actual Presidente de dicha República [...] ha sido un gobierno ilustrado, observante fiel de las leyes y prácticas democráticas que estas prescribían, discreto y prudente; pero á la vez enérgico cuando las circunstancias así lo han requerido. [...].

Los periódicos adversarios de la administración Caro [...] quéjanse de fraudes y de escamoteos de votos; mas sobre ser tales quejas de rigor en todas las oposiciones, sabido es que las impurezas son vicio inherente del sufragio público, de que ni los Estados Unidos se ven exentos. Lo importante es que haya sufragio efectivo, que sus vicios se podrán ir corrigiendo á medida que se practique. De bonísima gana quisiéramos que en México pudieran lanzarse análogas acusaciones al gobierno, puesto que ello sería señal cierta de que el voto público tenía existencia, siendo así que el sufragio entre nosotros, por desgracia, es práctica que está muerta, bien muerta [...], no conociéndose hoy por hoy más elector en esta República que el supremo Magistrado de ella. [...] Por indudables que sean las dotes de gobernante del General Díaz, que nosotros siempre le hemos reconocido, su continuada permanencia en el poder, de una parte, y de otra, la no intervención de los ciudadanos en el nombramiento de los funcionarios que deben ser elegidos popularmente, le quitan a

25 “Nueva Era”, Bogotá, 6 de febrero de 1898, s. p.

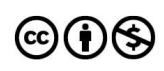


nuestro gobierno todos los caracteres de republicano, siendo en realidad de verdad, una manifiesta dictadura. ${ }^{26}$

La comparación realizada por este autor giraba alrededor de un eje medular; a saber, la existencia en el territorio patrio de un gobierno conservador ultra católico que contrastaba con el gobierno liberal de Porfirio Díaz, quien, sin ser anticatólico, le había otorgado gran preeminencia a "la religión de la ciencia” (González y González, 2010, p. 55). ${ }^{27}$ Los reproches proferidos contra el porfiriato partían de la convicción de que mientras hubiera comicios en los que participaran distintos candidatos que se disputaran la contienda electoral, se podría hablar de democracia efectiva; sin embargo, lo que Victoriano Agüeros no vislumbraba era que para los letrados colombianos este concepto significaba que no había traba alguna para sufragar: la pureza del sufragio era la libertad del ciudadano.

Los fraudes perpetrados por el carismo fueron, en consecuencia, interpretados por la oposición como la prueba fehaciente de que el único modo de recuperar la institucionalidad, de recobrar los derechos consignados en la carta magna, de volver a ser un país republicano, era a través de la guerra. La radicalización del descontento en el territorio patrio, sumada a la continuación de la crisis económica que experimentaba la nación, propició que el poder central expidiera a mediados de 1899 un decreto en el que se declaraba perturbado "el orden público en Cundinamarca, Boyacá y Santander", instrucción que de inmediato legitimó "las persecuciones y detenciones de individuos desafectos" al oficialismo (Martínez Carreño, 1999, p. 31). La represión a la que fue sometido el liberalismo en virtud de esta norma suscitó que en octubre de dicho año el partido declarara el comienzo de la guerra de los Mil Días. ${ }^{28}$

${ }^{26}$ Victoriano Agüeros, “Bogotá”, Bogotá, 22 de abril de 1898, s. p. También manifestaba en el texto su preocupación por quién iba a suceder a Porfirio Díaz cuando este ya no pudiera gobernar. Tal tópico lo inquietaba porque, desde su perspectiva, no habiendo persona con suficiente carisma para que le sucediera en el cargo, la herencia que iba a quedar era "el caos político" (s. p.).

${ }^{27}$ Un elemento a tener en cuenta para entender las particularidades de ambos regímenes es, según Javier Ocampo López (1986), la influencia que tuvo el positivismo spenceriano en el pensamiento nuñista, a diferencia del positivismo comtiano que predominó en el ámbito mexicano. Igualmente, si se quiere indagar acerca del papel cumplido por la Iglesia durante este periodo se recomienda leer el artículo de José David Cortés Guerrero (1997) citado en la bibliografía.

${ }^{28}$ De acuerdo con Carlos Martínez Silva (1973) “donde, al parecer, se centralizó la guerra durante los primeros días fue en Anapoima”, lugar en el que residía Manuel Antonio Sanclemente (p. 438).

\section{()(1) $\$$}


La intensidad de la confrontación acabó dibujando un escenario completamente diferente al que inicialmente se había pensado; aunque en un primer momento la lucha se libró de "manera convencional", lo cierto es que a raíz de la derrota de la oposición en la cruenta batalla de Palonegro (Santander), acaecida en mayo de 1900, "la tónica de la guerra cambió" (Bergquist, 2001, pp. 387-388). ${ }^{29}$ La incapacidad de Manuel Antonio Sanclemente para solucionar los problemas que acosaban a la patria fue aprovechada por los conservadores históricos para forjar una alianza con algunos liberales y organizar un "movimiento" que tenía como objetivo "la reconstrucción del orden constitucional desquiciado y del orden moral subvertido" mediante la destitución del presidente y la instauración en este cargo del vicepresidente José Manuel Marroquín. ${ }^{30}$

El corolario de ello fue el golpe de Estado efectuado el 31 de julio de 1900, el cual fue recibido por la opinión pública nacional como un augurio de que la paz "vendría muy pronto con el cambio efectuado". Tal certeza estaba afincada en la idea de que si se hubieran manejado con rectitud "escrupulosa los caudales públicos", si se hubiera seguido una directriz "de respeto a todos los derechos políticos de los ciudadanos", o si se hubieran escuchado oportunamente "las quejas de las poblaciones explotadas", la revolución no habría encontrado "el estímulo" adecuado para fructificar. ${ }^{31}$

La promesa del recién investido dignatario de "propender por el restablecimiento de un Gobierno justiciero, probo y enérgico para el bien" común, se erigió en el escenario perfecto para que los letrados de la época retomaran el debate sobre el tipo de régimen que debíamos implementar, en aras de erigirnos en una nación que mostrara el progreso propio de la "civilización

${ }^{29}$ Helen Delpar (1994) disiente de la caracterización que hace este autor de los históricos y de los nacionalistas para explicar por qué se dio la división al interior del conservadurismo; sin embargo, coincide con él en que esta guerra "sobrepasó a cualquiera de sus predecesoras por la devastación que trajo a la propiedad y a la organización social” (p. 417). Jorge Orlando Melo (1991) concuerda asimismo con tal apreciación; en su lenguaje: "en agosto de 1899 se lanzaron a la guerra, que algunos miembros del gobierno parecen haber esperado con gusto e incluso inducido, creyendo que sería una guerrita "de tres meses" que dejaría fortalecido al gobierno. Pero la contienda que comenzaba sería la más violenta y prolongada de la historia colombiana" (s. p).

${ }^{30}$ El autor de este artículo justificaba el golpe de Estado arguyendo que con el ministro de Gobierno, Rafael María Palacio, a quien el presidente Manuel Antonio Sanclemente le había confiado el mando, el país se encontraba sumido en una "dictadura". ESPECTADOR, "Es inútil", La Opinión, 4 de septiembre de 1900, p. 54.

31 "El veredicto", La Opinión, 3 de septiembre de 1900, p. 49.

\section{()ㅜ(1) $\$$}


moderna" ${ }^{32}$ La Opinión apeló a los planteamientos realizados años atrás por Federico C. Aguilar para afirmar que la causa de los males del país residía en que, a diferencia de otras repúblicas hispanoamericanas como Argentina, México y Perú, en Colombia se seguía fundamentando el adelanto nacional en el imperio de las ideas (sustrato del cual brotaba la política) pero no en el de los hechos, correspondiente al campo administrativo. ${ }^{33}$

La "administración", por consiguiente, "no había entrado para nada, o había entrado muy poco en los consejos del Gobierno y lo que debía ser objeto de ella, encaminado a un interés general, se había puesto al servicio de la política, convirtiendo a la primera en medio y a la segunda en fin exclusivo". ${ }^{34}$ La gravedad de la situación era tal, que a juicio de Antonio José Uribe la única salida posible para cambiar el rumbo "era hacer el deslinde" entre una y otra, separación que implicaba "dedicar las fuerzas de la nación al desarrollo material, a la creación de la riqueza y al bienestar social" ${ }^{35}$

La fórmula ya no se limitaba entonces a mantener un gobierno firme y centralizado, sino que paralelamente requería que la consecución de la prosperidad económica se erigiera en una prioridad. La manera de lograrlo residía en el reconocimiento de que el modelo porfiriano no sólo había sido exitoso por el robustecimiento de la autoridad sino, especialmente, por el énfasis que se le había dado a la administración. En los términos del jurista antioqueño:

A fin de demostrar hasta donde prevalece entre nosotros la tendencia á convertir todos los asuntos de Gobierno en cuestiones de política, bastará un solo hecho. Varias veces, seducidos por el extraordinario adelanto á que, en poco años, ha llegado México, se nos ha propuesto como modelo digno de imitarse el Gobierno del Sr. General Díaz, en cuanto á la firmeza con la que ha sabido robustecer la autoridad, creyendo que esto sólo, como al conjuro de magos, bastaría para ponernos al igual de aquel país. Lo cierto es que mientras México, dirigido por su hábil mandatario, sigue en continua obra de progreso, nuestros ferrocarriles están como tocados de parálisis; el papel-moneda se aumenta más y más, casi como único recurso fiscal; [y] las guerras civiles nos arruinan y desprestigian [...]. Y todo ello á pesar de que tenemos muchas riquezas naturales, una juventud enérgica é inteligente, una numerosa clase

32 J. M. Marroquín, "Manifiesto”, Diario Oficial, 2 de agosto de 1900, p. 509; Aguilar, 1884 , p. 27.

${ }_{33}$ "La administración”, La Opinión, 20 de octubre de 1900, p. 210.

34 “La administración”, La Opinión, 13 de septiembre de 1900, p. 81.

35 “La administración”, La Opinión, 13 de septiembre de 1900, p. 81.

\section{()(1) $\$$}


social de gran cultura, un Ejército disciplinado, de valor incomparable, y una masa popular sufrida, en su mayor parte laboriosa, elementos todos que dirigidos con acierto, podrían llevar á este país á un grado de progreso en el cual nada tendría que envidiar á sus hermanos de la América española.

El error ha consistido en confiarlo todo á la estructura constitucional [...] [dedicándose] a los juegos de la política, con descuido de la administración. En México se ha conservado el orden y al mismo tiempo se ha dado grande impulso al desarrollo material del país [...]. Así se explica que los partidos de oposición que, como el que defiende el ilustre redactor de $\mathrm{El}$ Tiempo, tienen cánones fundamentales de disidencia política con el Gobierno, juzguen, en lo general, provechosa y hasta necesaria, la administración del Sr. General Díaz.

Nadie duda que, especialmente en las Repúblicas de Hispanoamérica, son necesarios Gobiernos fuertes que puedan mantener la paz é ir educando a los pueblos para la vida civil; pero es preciso no olvidar tampoco que los gobiernos vigorosos, investidos casi de una autoridad sin contrapeso, deben, más que otro alguno, dar en compensación ejemplos de moralidad y dejar en pos de ellos un grande adelanto para los países que gobiernan. ${ }^{36}$

Tales apreciaciones marcaban un punto de inflexión frente a las reflexiones que durante décadas habían llevado a cabo los letrados colombianos en torno a cómo construir la nación: en vista de que el desencadenamiento de la guerra había puesto en evidencia que ese Estado unitario, firme, centralizado, había sido incapaz de sembrar la paz en el territorio patrio, era preciso encontrar un elemento al cual aferrarse para creer que era posible salir del atraso. La postura que Antonio José Uribe defendía, dentro de este contexto, abogaba por que el gobernante fuera un hombre moralmente ejemplar que, en vez de consumirse en "recriminaciones de partido", "disertaciones políticas" o "discusiones de tesis filosóficas", se preocupara por sostener el orden (principio fundamental de la Regeneración) y por "administrar bien, prácticamente, los intereses que le estaban confiados". ${ }^{37}$

36 "La administración", La Opinión, 19 de septiembre de 1900, p. 101.

37 "La administración", La Opinión, 20 de octubre de 1900, p. 210. El 1 de diciembre de 1900 Porfirio Díaz envió una misiva a "su Grande y Buen amigo" José Manuel Marroquín para participarle que había sido reelecto como presidente para el cuatrienio que comenzaba ese día y terminaba el 30 de noviembre de 1904. El mandatario colombiano contestó el mensaje el 12 de abril de 1901 deseándole prosperidad a México y ventura personal al dignatario. J. M. Marroquín, Cartas de gabinete, Porfirio Díaz, Diario Oficial, 20 de abril de 1901, p. 310.

\section{()(1) $\$$}


El lema orden y progreso característico del porfiriato fue, en suma, traducido al ámbito colombiano con la máxima orden y moralidad, noción esta última que significaba abolir la política de círculo y los clientelismos que impedían a los connacionales concentrarse en las cuestiones francamente relevantes para el desarrollo del país. La tarea de quien resultara elegido como presidente en las próximas elecciones era palmaria.

\section{EL “PORFIRIO” COLOMBIANO: RAFAEL REYES}

Rafael Reyes nació en 1849 en Santa Rosa de Viterbo, Boyacá, en un hogar cuya educación se distinguió por ser estricta, profundamente católica y afincada en la idea de que el trabajo era el único medio de ocupar una posición económica favorable. Igual que sucedió con Porfirio Díaz, su padre murió siendo pequeño, por lo que fue su madre, Antonia Prieto y Solano, la que se quedó a cargo de los cuatro hijos. La disciplina que les inculcó marcó la vida del futuro mandatario: desde pequeño se acostumbró a trabajar tanto para ayudar al sostenimiento de su casa, como para poder pagar la mensualidad del colegio en el que estudiaba (Lemaître, 1981, pp. 53-60; Reyes Nieto, 1986, pp. 19-25).

Historiográficamente se afirma que la etapa correspondiente a su infancia y a su juventud selló su carácter: hizo de él un hombre orgulloso, ambicioso, laborioso, educado para ser independiente económicamente, pero fiel a los principios de la caridad cristiana. ${ }^{38} \mathrm{~A}$ los 17 años decidió trasladarse a Popayán, ciudad en donde su medio hermano Elías tenía una firma comercial. Al comienzo fungió como dependiente del almacén pero luego, gracias a sus ahorros, se hizo socio industrial. Hacia 1869 decidió recorrer las montañas del sur occidente colombiano para obtener quina; tras establecer un negocio próspero, le propuso a su familia que empezaran la explotación de las selvas meridionales que bordeaban el Amazonas con el propósito de extraer las riquezas vegetales o minerales de la zona y exportarlas por el puerto del Pará (Lemaître, 1981, pp. 61-68; Reyes Nieto, 1986, pp. 72-97, 142-143). ${ }^{39}$

${ }^{38}$ Los biógrafos del general sostienen que leyó pocos libros en su juventud, justamente por lo restringido del ambiente cultural de la provincia boyacense (Gómez Restrepo, 1986, p. 11).

${ }_{39}$ La expedición que concretó esta idea, emprendida en los albores de 1874, fue importante para el país porque, aparte de fomentar que se ejerciera un dominio efectivo sobre zonas del territorio hasta entonces ignotas, abrió una ruta fluvial clave (la del Putumayo) para la introducción de artículos procedentes del Brasil.

\section{()(1) $\$$}


Los años transcurridos entre 1875 y 1884 significaron tanto la consolidación como la quiebra de la fortuna amasada por la casa Elías Reyes \& Hermanos; cuando bajó el precio de la corteza, al punto de que las ganancias recaudadas ni siquiera cubrían los costos de transporte, la compañía debió abandonar las existencias de quina que tenía en la selva, quedando con un pasivo que Rafael Reyes canceló con el paso del tiempo (Reyes Nieto, 1986, pp. 239-240). ${ }^{40}$ La victoria de los liberales radicales en la guerra civil de 1876 , acaecida durante esos años, lo afectó notoriamente porque causó la ruina de Popayán, urbe que no sólo lo había acogido en su seno, sino que además fue la que a posteriori le dio el respaldo para ser designado representante por el estado soberano del Cauca al Consejo Nacional de Delegatarios que elaboró la Constitución de 1886.

La preeminencia que el general rápidamente alcanzó en la política nacional tras este hecho, sumada al prestigio que adquirió como militar, fue precisamente la que ocasionó que José Manuel Marroquín lo nombrara como delegado para participar por el país en la Segunda Conferencia Internacional Americana que se realizó en suelo mexicano a fines de 1901 e inicios de 1902. ${ }^{41}$ Luego de tomar parte en dicho evento, Rafael Reyes resolvió radicarse definitivamente en México para estudiar con detalle el modelo implementado por Porfirio Díaz, sistema que él mismo definió como una administración fundamentada en un "industrialismo en grande escala" que, compaginado con la represión del bandolerismo, la reorganización de la Hacienda y la conformación de una extensa red ferroviaria, había logrado la pacificación del país (Lemaître, 1981, p. 269; Reyes, 1979, pp. 37).

\section{EL PORFIRISMO REYISTA}

Mientras esto acontecía en tierras aztecas, la guerra de los Mil Días continuó en el territorio nacional. José Manuel Marroquín, honrando el compromiso que había hecho al subir al poder de que "respetaría y haría respetar los derechos políticos y civiles de todos” los colombianos, expidió el Decreto 29 del 19

40 La bonanza quinera no duró mucho debido, por un lado, a que la extracción se basaba en la destrucción de los árboles silvestres y, por el otro, a que los ingleses llevaron la semilla a Ceilán y a la India y los holandeses a Java, montando amplias plantaciones que a la larga significaron el fin del mercado para Colombia, Ecuador, Perú y Bolivia (Reyes Nieto, 1986, p. 72).

41 Interesa señalar que la carrera de Rafael Reyes en la milicia inició defendiendo la causa nuñista en la "revolución de 1885" (Reyes Nieto, 1986, p. 243).

\section{()(1) $\$$}


de agosto de 1900 sobre orden público, en donde le ofrecía un "salvoconducto a las fuerzas o partidas revolucionarias" que entregaran sus armas dentro de los quince días siguientes a la publicación de la norma. ${ }^{42}$ "Las buenas intenciones" del dignatario, sin embargo, no duraron mucho; a los diez días suscribió otro documento en donde explicaba que había tomado la decisión de arremeter contra "los amigos de la revolución" apenas terminara el plazo señalado. ${ }^{43}$

La ola de violencia que se produjo a raíz de este anuncio propició un renacimiento de la ofensiva liberal que fue decisivo para que, después de firmado el Tratado del Wisconsin del 21 de noviembre 1902 que terminó la confrontación, se diera el levantamiento que culminó al año siguiente con "la exitosa separación de Panamá" (Bushnell, 1996, p. 220). ${ }^{44}$ La indignación suscitada entre los colombianos por la pérdida del istmo progresivamente fue transformándose en una desconfianza profunda frente el régimen, circunstancia que suscitó, ante la cercanía de los próximos comicios, que la prensa bogotana de la época comenzara a secundar la candidatura de Rafael Reyes a la presidencia. ${ }^{45}$

Tras conocerse los resultados de la jornada electoral llevada a cabo el 2 de febrero de 1904 que le dieron la victoria -por un escaso margen de doce votos-al general, empezó a circular la noticia de que el triunfo había sido obtenido gracias al fraude perpetrado con los registros de la provincia de Padilla en el departamento del Magdalena, acusación que obligó a que fuera el Gran Consejo Electoral el que pronunciara el veredicto final. La sentencia dictada el 4 de julio de 1904 por este organismo determinó que "no estaba legalmente

42 J. M. Marroquín, "Manifiesto", Diario Oficial, 2 de agosto de 1900, p. 509; J. M. Marroquín, Decreto número 29, 19 de agosto de 1900, sobre orden público, Diario Oficial, 23 de agosto de 1900 , p. 541.

${ }^{43}$ J. M. Marroquín, “Documento importante”, Boletín de Guerra, 29 de agosto de 1900, s. p.

${ }^{44}$ Rafael Reyes fue comisionado por José Manuel Marroquín para que, junto con Jorge Holguín, Pedro Nel Ospina y Lucas Caballero, buscara en representación de Colombia un arreglo con Estados Unidos. Vale anotar que no era la primera vez que él aceptaba un puesto de este tipo, pues a comienzos de 1902 había sido nombrado enviado extraordinario y ministro plenipotenciario ante los gobiernos de Costa Rica, El Salvador y los Estados Unidos Mexicanos (J. M. Marroquín, Decreto número 673, 24 de abril de 1902, Diario Oficial, 30 de junio de 1902, p. 365).

${ }^{45}$ La expectativa surgida en torno a su nombre no fue, empero, compartida por la totalidad de los conservadores; de acuerdo con algunas publicaciones, la opinión de las entidades departamentales favoreció a su contrincante, el cartagenero Joaquín Fernando Vélez quien, aparte de ser su compañero de armas en Panamá durante la guerra civil de 1885, tenía "las cualidades morales" para que sus copartidarios aseguraran que bajo su tutela se implementaría una administración pública honrada. "Necesidad del sufragio", El Espectador, 29 de octubre de 1903, p. 42.

\section{()(1) $(3$}


probado que la Asamblea electoral de esa demarcación no se hubiera reunido en la ciudad" de Riohacha en la fecha citada y que, por consiguiente, desde este "punto de vista" los sufragios emitidos no se podían anular (Pantoja, Coral, Goyes, et al., 1986, p. 163). ${ }^{46}$

La confirmación del escrutinio reavivó las comparaciones con el porfiriato: días después del anuncio, El Nuevo Tiempo publicó un artículo en el que, contradiciendo la tónica predominante a fines del siglo XIX, se cuestionaba la validez que tenía ese modelo en el contexto colombiano. Insistiendo en que era "bien singular que en vísperas de inaugurarse una nueva administración se hablara tanto del gobierno de Porfirio Díaz en México", el diario se preguntaba si era esa "la aspiración de alguno de los partidos políticos", o si en cambio constituía "el programa de algún candidato". ${ }^{47}$

La argumentación proporcionada por el periódico rechazaba la crítica que cuatro años atrás había realizado Antonio José Uribe en La Opinión en lo concerniente a centrar todo en la estructura constitucional. La pretensión del escrito era, en concreto, reivindicar la necesidad de construir instituciones que aseguraran, en el largo plazo, la prosperidad nacional:

Porfirio Díaz ha manejado las arcas nacionales con diamantina integridad; ha impulsado vigorosamente la administración pública; su reputación no se ha teñido con sombra de sospecha. Pero todo esto que abona y califica al mandatario, no comprueba, á nuestro juicio, la virtud de un mecanismo de Gobierno. El ideal de un tirano honrado y progresista [...] carece de significación ante la política experimental. Lo que esté fundado en la vida de un hombre, en sus especialísimas condiciones personales, ¿podrá erigirse en sistema? Sobre lo perecedero y caduco, ipodrá levantarse lo permanente y durable? [...]. [Sólo] sobrevive el bien donde ha logrado traducirse en instituciones permanentes y arraigado en la conciencia nacional. [...] El partido o nación que espera que su prosperidad o engrandecimiento le vengan de las capacidades de un hombre, por grandes que ellas sean, es como el jornalero que abandona el surco y en espera de un golpe de fortuna, compra un billete de lotería. El bienestar de un pueblo, como la dicha individual, es el precio

46 “Candidaturas”, El Derecho, 19 de enero de 1904, s. p. Rafael Reyes consiguió 994 votos y Joaquín F. Vélez 982 . Es pertinente mencionar que la labor del general como dignatario ha sido exaltada por la historiografía sobre el tema en virtud, primordialmente, de su carácter "pragmático, moderno", emprendedor, típico del hombre de negocios que sobresalió por sus propios méritos gracias al trabajo constante, la disciplina y el esfuerzo (Vélez, 1989, pp. 187-188).

47 “'Hombres o Instituciones?”, El Nuevo Tiempo, 11 de junio de 1904, s. p.

\section{()(1) $\$$}


del esfuerzo de todos, nunca interrumpido, diario, incesante. Debemos confiar en los gérmenes de vida que todo pueblo lleva en sí mismo. Fundada la paz, irrevocablemente ahí irá surgiendo la organización política que sintetice nuestras necesidades y que se halle más en armonía con nuestra manera de ser propia y castiza. ${ }^{48}$

El editorialista recurría a la preocupación que había entre los mexicanos por el futuro que le esperaba al país luego de la salida de Porfirio Díaz del mando, para argüir que Colombia necesitaba como nación un modelo propio que sintetizara sus necesidades, pero que a la par fuera afín a la manera de ser de su población. Las apreciaciones precedentes fueron respaldadas pocos días después por Miguel Antonio Caro, quien el 16 de junio de 1904 publicó en el diario El Eco Nacional un artículo titulado "El Porfirismo", en donde criticaba vehementemente a Rafael Reyes por querer "transformarse en otro hombre" -fenómeno que para el filólogo bogotano era un imposible "en el orden natural, moral y preternatural"-o, en su defecto, por querer imitar lo que ese hombre (Porfirio Díaz) había hecho en "una tierra" que no se condecía en nada con el territorio nacional (Valderrama, 1993, pp. 271 y 277). ${ }^{49}$

Interesa destacar ambos textos porque, al poner en entredicho la capacidad del general para conducir la República en función de un paradigma foráneo que no era acorde a la idiosincrasia colombiana, finiquitaban el debate que por dos décadas se había establecido en torno al tema: México había logrado el progreso que ostentaba por lo que era como pueblo, no por lo que un individuo había hecho de él. La patria, por ende, debía convertirse en lo que de antaño anhelaba a partir de su propio decurso, de los gérmenes de vida que llevaba en sus entrañas, y no de lo que podía observar, aprender, aplicar, imitar, de otras experiencias. ${ }^{50}$

48 “Hombres o Instituciones?”, El Nuevo Tiempo, 11 de junio de 1904, s. p.

49 En el lenguaje de Miguel Antonio Caro: "hay cosas que no pueden imitarse. Los dones de la naturaleza no se imitan, la grandeza no se imita. Los hombres grandes llevan impreso el sello de la originalidad. El que se esfuerce en imitarlos, se esfuerza, por el mismo hecho, en separarse del modelo que no imitó a otros. Nosotros estamos muy lejos de participar de ciertas ideas político-religiosas del general Porfirio Díaz, paladín y sostenedor constante de las leyes llamadas allá 'de reforma', usurpación de bienes eclesiásticos, secularización del Estado, separación absoluta del poder civil y el eclesiástico" (Valderrama, 1993, pp. 273-274).

50 El filólogo bogotano lo expresaba como sigue: "el hombre público no puede considerarse fuera de la tierra que lo ha producido, del ambiente en que se ha formado, de aquello que representa y a que está indisolublemente vinculado a su ser" (Valderrama, 1993, p. 271).

\section{()ㅜ(1) $\$$}




\section{LA REALIDAD DEL QUINQUENIO}

Incentivado por quienes clamaban por la "reconstrucción nacional", Rafael Reyes puso en marcha un programa de gobierno que, aunque en la letra aseguraba distinguirse por "el estricto acatamiento a la voluntad" del pueblo, "consignada en sus instituciones y leyes", en la práctica obró en sentido contrario. ${ }^{51}$ La legitimación inicial del régimen fue consecuente con las expectativas de la población: argumentando que "mucha administración y poca política" era el derrotero que Colombia "reclamaba de sus dignatarios", el general dio cabida a los liberales en el gabinete como prueba de que, en vez de beneficiar a determinado círculo, se enfocaría en lograr "la prosperidad y el engrandecimiento" de todos los colombianos. ${ }^{52}$

Otra estrategia que el boyacense empleó para ganarse la confianza de sus compatriotas fue asegurar que su única intención era ser simplemente "el Jefe de la Administración", lo cual implicaba que "los asuntos públicos no podían ser objeto de combinaciones políticas" ${ }^{53} \mathrm{La}$ alusión a este tópico lo que en el fondo buscaba era asegurar la obediencia del poder legislativo; por ello, aparte de recordarle a los legisladores el compromiso que habían contraído con el pueblo colombiano, por ser los responsables de dictar las leyes que le permitirían al país situarse a la altura de las repúblicas hermanas, también los instó - con la excusa de que no debían mediar en un gobierno meramente administrativo las directrices de partido- a que lo secundaran en los proyectos que pensaba acometer.

La concordia con la cual emprendió su mandato, empero, fue sólo momentánea: tan pronto comenzaron las deliberaciones de los congresistas, Rafael Reyes empezó a solicitar que le concedieran "autorizaciones especiales" para expedir, a través de disposiciones presidenciales, providencias de carácter económico tales como la imposición de nuevos gravámenes, el aumento de las tarifas aduaneras o la emisión de 100000000 de pesos en calidad de préstamo (Bushnell, 1996, p. 218). La actitud adoptada al principio por los parla-

51 "Posesión presidencial", El Nuevo Tiempo, 9 de agosto de 1904, s. p. El término reconstrucción nacional suponía: a) la reivindicación de la soberanía nacional; $b$ ) el fortalecimiento de la autoridad para impedir que otros departamentos siguieran el ejemplo de Panamá, yc) la recuperación económica y fiscal del país.

52 “Posesión presidencial”, El Nuevo Tiempo, 9 de agosto de 1904, s. p. Téngase en cuenta que este gesto albergaba un fin político específico: mostrarle a los conservadores que no lo habían respaldado en la votación, que podían terminar siendo excluidos del poder si se empecinaban en obstaculizar su gobierno.

53 “Posesión presidencial”, El Nuevo Tiempo, 9 de agosto de 1904, s. p.

\section{()(1) $\$$}


mentarios fue aceptar colaborar con el dignatario, pero a medida que fueron aumentando las prerrogativas, decidieron negarlas. La situación alcanzó niveles tan graves que en la prensa bogotana comenzó a discutirse si existía o no una dictadura, escenario que se constituyó en un indicio fehaciente de la polarización que estaba surgiendo alrededor de la figura del general. ${ }^{54}$

La acentuación de los problemas entre las dos instancias terminó originando el cierre del Congreso, así como la expedición del Decreto Legislativo 29 del 1 de febrero de 1905 por medio del cual se convocó a una Asamblea Nacional que, acreditada como Cuerpo Constituyente, quedó con la responsabilidad de efectuar las reformas que demandaba la patria. Tal prescripción estuvo acompañada, semanas más tarde, de la promulgación del Acto Legislativo 5 del 30 de marzo del corriente en donde se eliminaba la vicepresidencia, la designatura nacional (ambos cargos destinados a reemplazar al dignatario cuando fuera preciso), y se ampliaba el periodo presidencial a diez años, contados desde el 1 de enero de 1905 hasta el 31 de diciembre de $1914 .^{55}$

El accionar del mandatario se volvió a partir de entonces completamente dictatorial: sustentado en la Ley de Alta Policía Nacional que le permitía al gobierno confinar a prisión a todo individuo que con sus escritos o sus exhortaciones pusiera en riesgo la reorganización del país, le impuso una dura censura a la prensa. ${ }^{56}$ Igualmente, en aras de quebrantar los lazos políticos que se mantenían a nivel regional, alteró la división territorial vigente conformando nuevas secciones (posición que se contradecía con la defensa que, como delegatario al Consejo Nacional Constituyente, había hecho sobre la materia) e intervino en la conformación que en adelante tendrían los consejos municipales. Las consecuencias de este hecho no son irrisorias, pues cabe recordar que para entonces las municipalidades constituían la voz del pueblo: cada vez que el gobierno solicitaba la opinión de los colombianos, los cabildantes eran los responsables de expresar el sentir de su localidad. ${ }^{57}$

${ }^{54}$ La oposición se fraguó particularmente en la Cámara por parte de los representantes conservadores. El liberalismo, en contraposición, fue el partido que respaldó al mandatario.

55 “Labores de la Asamblea Nacional de Colombia en 1905”, El Observador, 3 de junio de 1905 , s. p.

${ }^{56}$ La Ley de Alta Policía Nacional había sido sancionada en el Decreto 918 del 27 de noviembre de 1904. Al mes de su expedición y ante la posibilidad de que los ejércitos que se encontraban en el Táchira (Venezuela) invadieran el territorio patrio, el ejecutivo dictó el Decreto 1045 de 1904 por medio del cual se estableció el estado de sitio en los departamentos de Cundinamarca y Santander (República de Colombia, 1905, pp. 3-4).

57 También clausuró la municipalidad bogotana; abolió las asambleas departamentales; aplazó indefinidamente las elecciones populares para cabildantes en el resto del territo-

\section{()ㅜ(1) $\$$}


La acentuación del inconformismo que empezó a sentirse en el territorio patrio a partir del primer año del régimen reyista alcanzó su punto de quiebre luego del atentado perpetrado en contra del general el 10 de febrero de 1906 en Bogotá (Lemaître, 1981, pp. 325-326). La represión ejercida por las autoridades estatales a raíz de este acaecimiento (arrestos arbitrarios, destierros, ejecuciones, etc.), marcó el comienzo de la caída del Quinquenio. ${ }^{58} \mathrm{La}$ opinión pública que inicialmente había respaldado a Rafael Reyes acabó convirtiéndose en una de las principales detractoras de su gestión, situación que propició que para principios de 1909 en los diarios de la época se le calificara abiertamente de dictador. El talante autoritario del dignatario, claramente exteriorizado en su necesidad de controlar desde la presidencia todo lo que sucedía en el país, generó que aquellos connacionales que habían depositado sus esperanzas en él para conseguir la descentralización administrativa prometida en la carta magna, eventualmente optaran por alinearse en la oposición.

Las voces que comenzaron a pedir insistentemente que se llamara a comicios parlamentarios para instaurar un Congreso de carácter popular, aunadas con las críticas que se hacían frente a los tratados que Colombia estaba considerando realizar con Estados Unidos y Panamá, tuvieron como corolario la organización de las manifestaciones del 13 de marzo de 1909 que, meses después, ocasionaron la salida al exilio del mandatario (Pantoja, et al., 1986, pp. 341-344). La abrupta salida del boyacense del poder hizo tangible, en suma, su incapacidad para entender que las instituciones establecidas en la Constitución de 1886 debían respetarse, e incluso, que si era preciso reformarlas, debía hacerse con estricta observancia de la norma. La figura del dictador, como algunos editorialistas de la época lo habían remarcado, no tenía asidero para perpetuarse en el contexto colombiano. ${ }^{59}$

rio patrio, e impuso su voluntad en el ente legislador. De hecho, los asambleístas, en vez de deliberar sobre las reformas que se debían adelantar, se limitaron a suscribir las propuestas redactadas desde la presidencia ("Labores de la Asamblea Nacional de Colombia en 1905”, El Observador, 3 de junio de 1905, s. p.).

${ }^{58}$ La investigación doctoral pone en evidencia que ese centralismo obró como el punto de quiebre del régimen; aunque Rafael Reyes se dio cuenta de esto hacia 1908 y quiso cambiar de estrategia, otorgándole a los municipios y departamentos amplias facultades, lo cierto es que para entonces ya era demasiado tarde.

${ }_{59}$ Aunque los cinco años que duró el Quinquenio no son equiparables a las tres décadas que permaneció Porfirio Díaz en el poder, es pertinente anotar que, por más similitudes que existan entre ambos dignatarios, los connacionales eran absolutamente contrarios a la existencia de un dictador: el gobierno firme que continuamente se exigía, no entrañaba de ninguna manera que fuera dictatorial. Inclusive, en un editorial de El Comercio (1904) se llegó

\section{()(1) $\$$}




\section{EL PLANTEAMIENTO FINAL}

La postura apologética con la que frecuentemente se ha interpretado el Quinquenio, particularmente encarnada en la obra de Eduardo Lemaittre (1981), ha impedido analizar en su justa dimensión el régimen reyista: la "dictadura moderada" de la cual habla David Bushnell (1996, p. 219) o la explicación dada por el cartagenero para justificar que el general hubiera tenido que optar por la dictadura, son pruebas irrefutables de la lectura tendenciosa con la que se han reconstruido algunos periodos de la historia colombiana. ${ }^{60}$

La tendencia predominante en el ámbito académico nacional ha sido reproducir la idea de que el gobierno reyista promovió "la modernización tanto económica como tecnológica del territorio patrio", dando así origen a "los comienzos del Estado moderno" (Bushnell, 1996, p. 219; Mesa, 1980, p. 96). ${ }^{61}$ Quienes secundan este planteo incluso aseveran que el general rompió con la tradición política de la Regeneración al adoptar una posición pluralista (e incluso, suprapartidista) que proscribió "el control exclusivo sobre todas las manifestaciones de la vida social" que hasta entonces había tenido el partido nacional (Vélez, 1989, p. 190).

Tal como lo demuestran las fuentes, esta aserción no se corresponde con la realidad de la época: un análisis riguroso hace evidente que el boyacense sí buscó convertirse en el jefe único del conservatismo al pretender ser el candidato, tanto de los nacionalistas como de los históricos, en las elecciones de 1898; de hecho, la humillación política que sufrió por parte de ambos bandos al descubrirse su proceder, fue la que originó que en su discurso de posesión declarara que él "no sería ni había aspirado nunca á ser jefe de partido sino Jefe de la Administración”, aserción que anunciaba su intención de

a aseverar que el "medio ambiente bogotano jamás había sido propicio al terrorismo ni a las dictaduras" ("En defensa de Bogotá", El Comercio, 18 de junio de 1904, s. p.).

${ }^{60}$ Lemaître (1981) asevera que si Rafael Reyes hubiera gobernado "en un país de más avanzada civilización política" quizá "no solamente habría sido un buen administrador de la cosa pública, sino un gobernante ejemplar en cuanto al estricto cumplimiento de las normas y las reglamentaciones constitucionales". No obstante, "los tiempos eran malos y una serie de acontecimientos concatenados iban a conducir al nuevo mandatario hacia el único camino que, en épocas de tormenta, suelen tomar todas las repúblicas: la dictadura" (p. 271). Los argumentos precedentes, en efecto, no se desligan mucho de lo que decían los propios apologistas de Porfirio Díaz (caso de Francisco Bulnes y José López Portillo) sobre el porfiriato; a saber, "la dictadura más noble y más buena que se había conocido en el mundo" (Tenorio y Gómez, 2006, p. 8).

${ }^{61}$ Las ideas aquí consignadas fueron presentadas en el Seminario de AcIUR que se realizó en Cali en septiembre de 2016.

\section{()(1) $\$$}


convertirse en jefe único de la nación, allende si tenía el apoyo o no de los partidos (Pedraza, 1909, p. 61). ${ }^{62}$ Las palabras de Carlos E. Restrepo (1930) son ilustrativas en este sentido:

Lo primero que hizo Reyes fue acabar con los partidos y con las fracciones de los partidos. [...] Ha tenido este [...] la habilidad suficiente para establecer un perfecto equilibrio entre liberales y conservadores, y hoy sostienen los conservadores al Presidente porque temen perder el poder, y lo sostienen los liberales porque esperan conseguirlo por conducto del mismo Mandatario. De este modo, amenazados unos y esperanzados los otros, Reyes hace que los partidos se vigilen y se teman, que no se unan y que no se organicen (pp. $231-232){ }^{63}$

Historiográficamente persiste el debate acerca de si Porfirio Díaz fue o no un dictador; aunque los historiadores mexicanos tienen desacuerdos al respecto, en lo que sí hay un cierto consenso es en que el porfiriato fue una

${ }^{62}$ La candidatura de Rafael Reyes se malogró porque poco antes de las elecciones se reveló que él había entablado conversaciones con el nacionalismo para obtener el apoyo de este partido, conducta que generó la indignación de los conservadores históricos, quienes le quitaron el aval nombrando en su reemplazo al general Guillermo Quintero Calderón.

${ }^{63}$ Quizá el fracaso más rotundo de Rafael Reyes (cosa que no sucedió en México) fue, justamente, no haber conseguido anular por completo a los partidos o subsumirlos bajo su figura, como de hecho lo intentó. Lo que logró, en contrapartida, fue fomentar la conformación de una coalición partidista (la Unión Republicana) que tuvo como único propósito hacerle oposición. La historiografía considera -caso, por ejemplo, de Eduardo Posada Carbó (2015) - que este movimiento fue liderado por Carlos E. Restrepo; no obstante, cuando se examina esta cuestión desde lo local, se pone en evidencia que los líderes de este partido fueron el general Guillermo Quintero Calderón y el liberal Nicolás Esguerra. Vale la pena anotar que la Junta Republicana, que fue la que dio origen a dicho movimiento político, fue conformada el 26 de marzo de 1909 por partidarios del liberalismo, el conservadurismo y el nacionalismo para encarar los comicios al Congreso, quedando de esta manera separada de los conservadores de la Concentración Conservadora dirigidos por Marco Fidel Suárez y de los liberales del Bloque Liberal comandados por Rafael Uribe Uribe. La trascendencia que aquella alcanzó en la recuperación de la institucionalidad en el país queda claramente demostrada al evidenciarse que todos sus candidatos fueron elegidos con amplia mayoría en las elecciones municipales realizadas en Bogotá en noviembre de 1909 (Suárez, 2015, pp. 312333). Interesa remarcar, finalmente, que el propio Rafael Reyes se percató de la importancia de Nicolás Esguerra como contradictor político, prueba de lo cual es que intentó cooptarlo para sus intereses ofreciéndole el Ministerio de Obras Públicas; el rechazo a dicho ofrecimiento por parte del liberal bogotano -a quien los historiadores colombianos le hacen poca justicia-fue lo que propició que Nemesio Camacho llegara al cargo.

\section{()(1) $\$$}


dictadura ${ }^{64}$ La historiografía surgida en la esfera colombiana en torno a la figura de Rafael Reyes se caracteriza, en contrapartida, por minimizar el carácter dictatorial del gobierno reyista, acaecer que pone de manifiesto la urgencia de empezar a problematizar la historia colombiana cambiando la escala de análisis. ${ }^{65}$ La realidad del proceso histórico experimentado por el país durante estas décadas resulta, en efecto, totalmente distinta cuando se mira el problema priorizando el nivel de lo micro: si se examinan cuidadosamente los documentos del periodo en estudio no sólo es factible afirmar que Rafael Reyes no fue un modernizador, sino que además sus actuaciones fueron las de un dictador. ${ }^{66}$

Las disposiciones que adoptó en materia territorial, fiscal, pero especialmente, con respecto a la esfera municipal, así lo confirman. Tras cinco años de ocurrida la pérdida de Panamá, las denuncias de la opinión pública (corrupción, clientelismo, atraso, penurias económicas, etc.), eran las mismas que en el pasado: la nación colombiana, a diferencia de lo que había sucedido en México, no mostraba signos contundentes de recuperación. ${ }^{67}$ La carestía de los alimentos básicos, la postración de la industria, las quiebras de los bancos, la falta de crédito, las continuas denuncias sobre favoritismos, contratos leoninos y corrupción en las oficinas públicas eran, por consiguiente, síntomas palpables de que la política había primado frente a la administración.

${ }^{64}$ Paul Garner (2015) habla de un antiporfirismo, un porfirismo y un neoporfirismo para expresar las múltiples tendencias historiográficas que hay en relación con Porfirio Díaz. En tal sentido, si bien no vacila en calificarlo de dictador, advierte que este concepto se aleja del retrato de dictador brutal que le otorgaron aquellos historiadores que reivindicaron el legado de la revolución mexicana.

${ }^{65}$ Eduardo Posada Carbó (2015) es uno de los contados historiadores colombianos que afirma tajantemente que Rafael Reyes fue un dictador y que su gobierno fue una dictadura.

${ }^{66}$ El concepto de lo micro remite a los planteamientos de Serna y Pons (2000). Las fuentes que se privilegiaron en esta investigación corresponden a la capital del país, razón por la cual es preciso fomentar este tipo de pesquisas en otras zonas para confrontar los resultados; sin embargo, mientras en Colombia permanezcan sin explorarse numerosas vetas de análisis que ayuden a esclarecer, en cifras concretas, cuál fue el progreso material alcanzado durante el Quinquenio, seguramente seguirá siendo difícil dimensionar esa modernización reyista que la historiografía se ha encargado de ensalzar. En tal dirección, sería importante hacer un estudio más detallado de lo que se obtuvo en rentas y de lo que se invirtió, no sólo a nivel nacional, sino especialmente a nivel departamental y municipal.

${ }^{67}$ No se desconoce, empero, que hubo avances en ciertos aspectos, como por ejemplo, en cuanto a vías de comunicación: el general conocía quizá mejor que nadie en la época el territorio patrio y sabía, por experiencia, que tender rutas era imprescindible para poder fomentar el comercio y la industria nacional.

\section{(ㄷ)(1) $(3$}


Importa subrayar, dentro de este marco, que la historiografía nacional, en vez de profundizar en las fuentes primarias, ha dado por sentado que la admiración que el general sentía por el mandatario mexicano se tradujo en un plan programático análogo, materializado durante el Quinquenio. Lo cierto es, empero, que el quid de la cuestión no radicó en la valía innegable que adquirió el porfiriato a finales del siglo xIx y principios del xx como modelo de gobierno, sino en el hecho de que las transformaciones a largo plazo no eran producto de un hombre sino de una sociedad.

Mucha administración y poca política fue un lema que no se aplicó a cabalidad durante el reyismo porque el dignatario creyó que ser el gobernante firme que era Porfirio Díaz significaba ser el jefe absoluto, único, de ambas esferas: administrativamente, su equivocación consistió en no permitirle a las regiones adquirir la autonomía que anhelaban; políticamente, su error de cálculo estuvo en pensar que podía gobernar sin darle participación a la elite nacional que en buena medida estaba afincada en la capital. ${ }^{68}$

Finalmente, la partida de ambos mandatarios al exilio se explica en función de un mismo problema: la institucionalidad. Algunos historiadores sostienen que lo que incentivó la rebelión en México fue que Porfirio Díaz no vio instituciones a futuro; el miedo de ciertos mexicanos por lo que iba a pasar después del porfiriato no era, por lo tanto, injustificado. ${ }^{69}$ Lo acontecido en Colombia fue algo diametralmente opuesto: en el país el respeto a las instituciones estaba tan arraigado (pese a que en la práctica continuamente se pusieran en entredicho) que anularlas suponía quebrantar los tres principios de la nación que los letrados de la época consideraban inquebrantables: republicanismo, democracia e institucionalidad.

${ }^{68}$ Una cuestión a señalar, dentro de este contexto, es que la personificación de la autoridad que representaba Porfirio Díaz no iba en contravía de la conformación de una elite política, científica, letrada, que estuviera al servicio del régimen. La posición del boyacense en este asunto fue totalmente diferente: el odio que sentía hacia los demagogos bogotanos, lo llevó a excluirlos de todas las instancias gubernamentales, decisión que le impidió cooptar para su propio beneficio las masas que esa clase alta dominaba. Sobre este tema, véase Suárez (2015, p. 81).

${ }^{69}$ Indiscutiblemente, la historiografía colombiana está en mora de realizar un buen análisis comparativo de estos dos mandatarios que ayudaría a entender mejor sus respectivos regímenes.

\section{()(1) $(3$}




\section{LISTA DE REFERENCIAS}

Aguilar, F. C. (1884). Colombia en presencia de las Repúblicas Hispano-americanas por el presbitero Dr. Federico C. Aguilar. Bogotá: Imprenta de Ignacio Borda.

Bergquist, C. W. (2001). Una comparación entre la Guerra de los Mil Días y la crisis contemporánea. En G. Sánchez y M. Aguilera (comps.), Memoria de un país en guerra. Los Mil Días, 1899-1902 (pp. 387-402). Bogotá: IEPRI/Editorial Planeta.

Bushnell, D. (1975). Aspectos de la historia electoral colombiana del siglo xIx. En Lecturas de Historia. Política y sociedad en el siglo XIX (pp. 28-38). Tunja: Ediciones "Pato Marino".

Bushnell, D. (1996). Colombia: una nación a pesar de sí misma: de los tiempos precolombinos a nuestros días. Bogotá: Planeta Editores.

Cané, M. (1992). Notas de viaje sobre Venezuela y Colombia. Bogotá: Tercer Mundo Editores.

Colomer, E. (1997). Movimientos de renovación: Humanismo y Renacimiento. Madrid: Ediciones Akal.

Cortés Guerrero, J. D. (1997). Regeneración, intransigencia y régimen de cristiandad. Historia Crítica, 15, 3-12. Recuperado de https://historiacritica.uniandes.edu.co/ view.php/128/1.php

Deas, M. (1983). La Regeneración y la guerra de los Mil Días. En A. Martínez Carreño (ed.), Aspectos polémicos de la historia colombiana del siglo XIX. Memoria de un seminario (pp. 51-94). Bogotá: Fondo Cultural Cafetero.

Deas, M. (1993). La presencia de la política nacional en la vida provinciana, pueblerina y rural de Colombia en el primer siglo de la República. En Del poder y la gramática. Y otros ensayos sobre historia, política y literatura colombianas (pp. 175-206). Bogotá: Tercer Mundo Editores.

Delpar, H. (1994). Rojos contra azules. El partido liberal en la política colombiana 18631899. Colombia: Procultura.

García Mérou, M. (1989). Impresiones. Bogotá: Academia Colombiana de Historia/Alcaldía Mayor de Bogotá.

Garner, P. (2015). Porfirio Díaz: entre el mito y la historia. México: Editorial Crítica.

Gómez Muller, A. (2011). Imaginarios de la "raza" y la "nación” en Rafael Núñez. En L. Múnera Ruiz y E. Cruz Rodríguez (eds.), La regeneración revisitada: pluriverso y hegemonía en la construcción del Estado-nación en Colombia (pp. 125-154). Medellín: La Carreta Editores.

Gómez Restrepo, S. (1986). José Domingo Ospina Camacho. En B. Ramírez (ed.), Biografía de los constituyentes 1886 (T. IV, pp. 5-98). Bogotá: Banco de la República.

\section{()(1) $\$$}


González y González, L. (2010). Alba y ocaso del porfiriato. México: Fondo de Cultura Económica.

Lemaître, E. (1981). Rafael Reyes. Biografía de un gran colombiano. Bogotá: Banco de la República.

Maquiavelo, N. (1983). El príncipe. Bogotá: Editorial Oveja Negra.

Martínez, F. (2001). El nacionalismo cosmopolita. La referencia europea en la construcción nacional en Colombia, 1845-1900. Bogotá: Banco de la República.

Martínez Carreño, A. (1999). La guerra de los Mil Días. Testimonios de sus protagonistas. Bogotá: Editorial Planeta.

Martínez Silva, C. (1973). Capítulos de historia política de Colombia (T. III). Bogotá: Biblioteca Banco Popular.

Melo, J. O. (1989). La Constitución de 1886. En C. Calderón Schrader (ed.), Nueva historia de Colombia. I. Historia política 1886-1946 (pp. 43-64). Bogotá: Planeta Colombiana Editorial.

Melo, J. O. (1991). La República conservadora. En Colombia Hoy. Recuperado de http://www.banrepcultural.org/blaavirtual/historia/colhoy/colo5.htm

Mesa, D. (1980). La vida política después de Panamá. 1903-1922. En J. Jaramillo Uribe (ed.), Manual de historia de Colombia (pp. 80-176). Bogotá: Colcultura.

Múnera Ruiz, L. (2011). El Estado en La Regeneración. (¿La modernidad política paradójica o las paradojas de la modernidad política?). En L. Múnera Ruiz y E. Cruz Rodríguez (eds.), La regeneración revisitada: pluriverso y hegemonía en la construcción del Estado-nación en Colombia (pp. 13-75). Medellín: La Carreta Editores.

Núñez, R. (1945a) La reforma política en Colombia (T. I [1]). Bogotá: Editorial Antena.

Núñez, R. (1945b). La reforma política en Colombia (T. I [2]). Bogotá: Editorial Antena. Núñez, R. (1986). Escritos políticos. Bogotá: El Áncora Editores.

Ocampo López, J. (1986). Positivismo spenceriano y tradicionalismo en la Constitución de 1886. La Regeneración. UNIV. HUM, 15(26), 53-72.

Ortiz Mesa, L. J. (2010). La Regeneración en Colombia (1878-1902). En D. Bonnet Vélez, M. J. LaRosa, y M. Nieto Olarte (eds.), Colombia. Preguntas y respuestas sobre su pasado y su presente (pp. 231-253). Bogotá: Ediciones Uniandes.

Palacios, M. (2001). Entre la legitimidad y la violencia. Colombia 1875-1994. Bogotá: Grupo Editorial Norma, 4a. ed.

Palacios, M. (2002). La Regeneración ante el espejo liberal y su importancia en el siglo xx. En R. Sierra Mejía (ed.), Miguel Antonio Caro y la cultura de su época (pp. 261278). Bogotá: Universidad Nacional de Colombia.

Pantoja, L. A., Coral Bastidas, J., Goyes Moreno, I., et al. (1896). Rafael Reyes. En B. Ramírez (ed.). Biografía de los constituyentes 1886 (T. IV, pp. 99-388). Bogotá: Banco de la República.

\section{()(1) $(2$}


Pedraza, P. A. (1909). Excursiones presidenciales. Apuntes de un diario de viajes. Estados Unidos: The Plimpton Press

Posada Carbó, E. (1995). Civilizar las urnas: conflicto y control en las elecciones colombianas, 1830-1930. Boletín Cultural y Bibliográfico, 32(39), 3-25.

Posada Carbó, E. (2015). Colombia. La apertura al mundo (T. 3. 1880/1930). Madrid: Fundación MAPFRe.

Rama, A. (1984). La ciudad letrada. Hanover: Ediciones del Norte.

República de Colombia (1888). Reglamentos del Senado y Cámara de Representantes de la República de Colombia. Bogotá: Imprenta de Antonio María Silvestre.

República de Colombia (1905). Decretos legislativos expedidos en 1904 y 1905. Bogotá: Imprenta Nacional.

Restrepo, C. E. (1930). Orientación republicana (t. I y II). Medellín: Librería de A. J. Cano.

Reyes, R. (1979). A través de la América del Sur. Exploraciones de los hermanos Reyes. Trabajo presentado en la II Conferencia Pan-Americana reunida en México por el General $R$. Reyes, delegado de Colombia. Bogotá: Flota Mercante Grancolombiana.

Reyes Nieto, E. (1986). Rafael Reyes. Memorias, 1850-1885. Bogotá: Fondo Cultural Cafetero.

Roeder, R. (2013). Hacia el México moderno: Porfirio Díaz (T. I). México: Fondo de Cultura Económica, 5a. ed.

Schmitt, C. (1991). El concepto de lo político. Madrid: Alianza Editorial.

Serna, J. y Pons, A. (2000). Cómo se escribe la microhistoria. España: Universitat de València.

Suárez Mayorga, A. M. (2006). La escenificación del poder en el espacio urbano capitalino. Bogotá, 1870-1910 (Tesis de maestría inédita). Universidad Nacional de Colombia, Colombia.

Suárez Mayorga, A. M. (2015). Bogotá en la lógica de la Regeneración. Indagando sobre el papel cumplido por el Municipio en la conformación del Estado nacional a partir del análisis de la administración capitalina, 1886-1910 (Tesis de doctorado inédita). Universidad de Buenos Aires, Argentina.

Tenorio Trillo, M. y Gómez Galvarriato, A. (2006). El porfiriato. México: Fondo de Cultura Económica/cide.

Uribe Uribe, R. (1910). Orígenes del poder municipal. Boletín de Historia y Antigüedades, vi(64), 211-241.

Valderrama Andrade, C. (1993). Miguel Antonio Caro. Escritos políticos. Cuarta serie. Bogotá: Instituto Caro y Cuervo.

\section{()ㅜ(1) $\$$}


Vélez, H. (1989). Rafael Reyes: Quinquenio, régimen político y capitalismo (19041909). En C. Calderón Schrader (coord.), Nueva Historia de Colombia (T. I. Historia política. 1886-1946, pp. 187-214). Bogotá: Editorial Planeta Colombia.

\section{OTRAS FUENTES}

Hemerografía

Bogotá.

Boletín de la guerra.

Diario Oficial.

El Comercio.

El Derecho.

El Espectador.

El Observador.

El Orden.

El Nuevo Tiempo.

El Sufragio.

La Opinión. 